\title{
OPTIMIZATION OF ENVIRONMENTAL ENGINEERING PROTECTION AND WATER RESOURCE USE AT THE MOST WATERED MINE IN UKRAINE
}

\section{Sadovenko I.O.}

Dnipro University of Technology, Dnipro, Ukraine, Dr. of Tech. Sciences, Professor, Professor of Dept. Hydrogeology and Engineering Geology

\section{Rudakov D.V.}

Dnipro University of Technology, Dnipro, Ukraine, Dr. of Tech. Sciences, Professor, Head of Dept. Hydrogeology and Engineering Geology

Zahrytsenko A.M.

Dnipro University of Technology, Dnipro, Ukraine, $\mathrm{PhD}$ in Tech. Sciences, Assoc. Professor, Assoc. Professor of Dept. Hydrogeology and Engineering Geology

\section{Derevaygina N.I.}

Dnipro University of Technology, Dnipro, Ukraine, PhD

in Tech. Sciences, Assoc. Professor of Dept. Hydrogeology and Engineering Geology

\begin{abstract}
This study deals with the environment protection of mining areas affected by flooding and waterlogging in Western Donbas. We used finite difference numerical modelling to analyse the hydrogeological regime of mining sites as complex geotechnical systems being transformed under the multifactorial influence and parameter uncertainty. The developed ground water flow model of the most waterabundant mine in Ukraine named after N.I. Stashkov has been validated using the available data on chronological stages of mining. This enabled to identify the patterns of temporal and spatial changes of flow parameters, the locations of high transmissivity zones in rocks and balance water flows in carboniferous and shallow aquifers.

Using the model we assessed the hydrodynamic conditions expected after closing and flooding the mine, particularly, the risks of near-by mine operation and environmental consequences to the ground surface. The groundwater level rebound is expected to take three years with emerging the zones of potential flooding and waterlogging in the Samara River floodplain. We compared four options of environmental engineering protection including the installation of stationary or submersible pumps in the mining horizon used for drainage, with evaluating the cost-effectiveness and anticipated environmental effect. The alternative option has been recommended to
\end{abstract}


protect the floodplain from waterlogging by installing a groundwater intake in high permeable sandstones in the paleochannel.

\section{Introduction}

Water regulation is one of the key issues at every stage of coalmining, beginning from commissioning and pitting into operation to closure and the post-mining period. Water regulation influences both the company profitability and environmental and technical safety [1$3]$. The water issues are the most challenging in terms of predictability and possibility to control due to intensive man-made transformations of rocks. A clear vertical zonation of the water exchange rate formed under natural conditions was violated during mining, with the zone of intensive water exchange extending down due to excavation roof collapse. This enhanced hydraulic connection between underground excavations, cover sediments, and surface watercourses; thus increasing the mine water inflow and the depletion of fresh water reserves.

Exhausting mineral reserves inevitably approaches the stage of closure designing and decommissioning that should take into account significant changes of ground water flow boundaries, flow and capacity parameters of rocks, ground surface subsidence, hydrochemical inversion etc. [4]. As a result of mine level rebound the flooded drainless areas appear in post-mining territories. Enhanced hydraulic connection among the mines determines the need to elaborate the measures on hydraulic protection of near-by active mines. Therefore, a tool for prediction and control over the processes accompanying flooding the mines as well as assessments for efficiency improvement of engineering solutions is getting of growing importance for mining areas of Ukraine.

A number of different methods and techniques have been used last decades to predict flooding the mines methods; they include finite difference method [5], finite element method [6], balance method in the form of the Box model [7, 8]. Finite-difference numerical models of ground water flow for the full life-cycle of a mine taking into account subgrid scale stochastic heterogeneity of affected rock and flow properties were proposed and tested in [9].

Besides, an analytical model of flooding the mines was first presented in [9] and further developed in [10]; it extended the known "big well" approach [11] to non-steady case and took into account 
vertical heterogeneity and, as distinct to existing analytical methods, temporal mine water level variation. The model allows easier and closer to reality analysing mine water rebound in case of hydraulically isolated mines but faces difficulties in simulating ground water flow in multiple adjacent coalfields with complex 3D geometries of mined out space.

Up to now, the widely used and most common and reliable method for predictive assessments of flooding multiple hydraulically connected mines is finite-difference modelling that takes into proper account 3D rock heterogeneity and complex geometry of geological formations, time-dependent boundary conditions and other factors, crucial for reliable evaluations and engineering protection design [12, 13].

In the Western Donbas, the challenges of the forthcoming mine closure become highly relevant in terms of emerging risks to the safety of active drained near-by mines. Beyond that, about $75 \%$ of the region's coal reserves are located in topographic lows and river floodplains with complicated hydrogeological conditions for mining.

The operating company DTEK plans to close the mine named after N.I. Stashkov as one of the most watered mine in Ukraine by 2021; the outflow of this mine significantly affects the hydrogeological conditions in near-by coalfields and the groundwater level in shallow aquifers. For this reason, the parameters of flooding the mine named after N.I. Stashkov should be optimized in the near future under the criteria of cost-effectiveness and mitigation of environmental impact including restoration of natural hydrogeological conditions.

In this regard, this study aims to optimize the environmental engineering protection and water resource use at the mine to be closed by adapting the method of predicting groundwater flow to the specifics of mined out coalfields.

\section{Methods}

To identify the patterns of temporal and spatial changes of the groundwater regime in the selected site we used the finite-difference method and the software MIF developed at the Ukrainian State Geological-Prospecting Institute (Dnipro, Ukraine). This software was applied to hydrogeological analysis of numerous sites in Ukraine including water regulation issues in mining areas [14, 15]. Numerical modelling of mining hydrodynamics included evaluation of ground- 
water regime parameters for the period of active coalmining and predictive calculations for closure and the post-mining period.

The developed numerical groundwater flow model reproduces the real mining site in terms of analogy to its geological settings and hydraulic response to man-made interventions including underground mining and operation of water storage ponds, water intakes, pumping stations, drainage facilities, etc. The model calculates groundwater flow parameters in the upper cover sediments and the lower water permeable carboniferous rocks with coal seams hydraulically connected by the shafts.

The model allows varying the technical parameters of water regulations and making assessments of the effect of water management measures on improving environmental safety on mining areas.

\section{Model development and validation}

The groundwater flow model covers the territory of two near-by coalfields (mines "Dniprovska" and named after N.I. Stashkov) hydraulically connected through the Buchak aquifer, and the coalbearing rocks separated by a tectonic fault (Fig. 1).

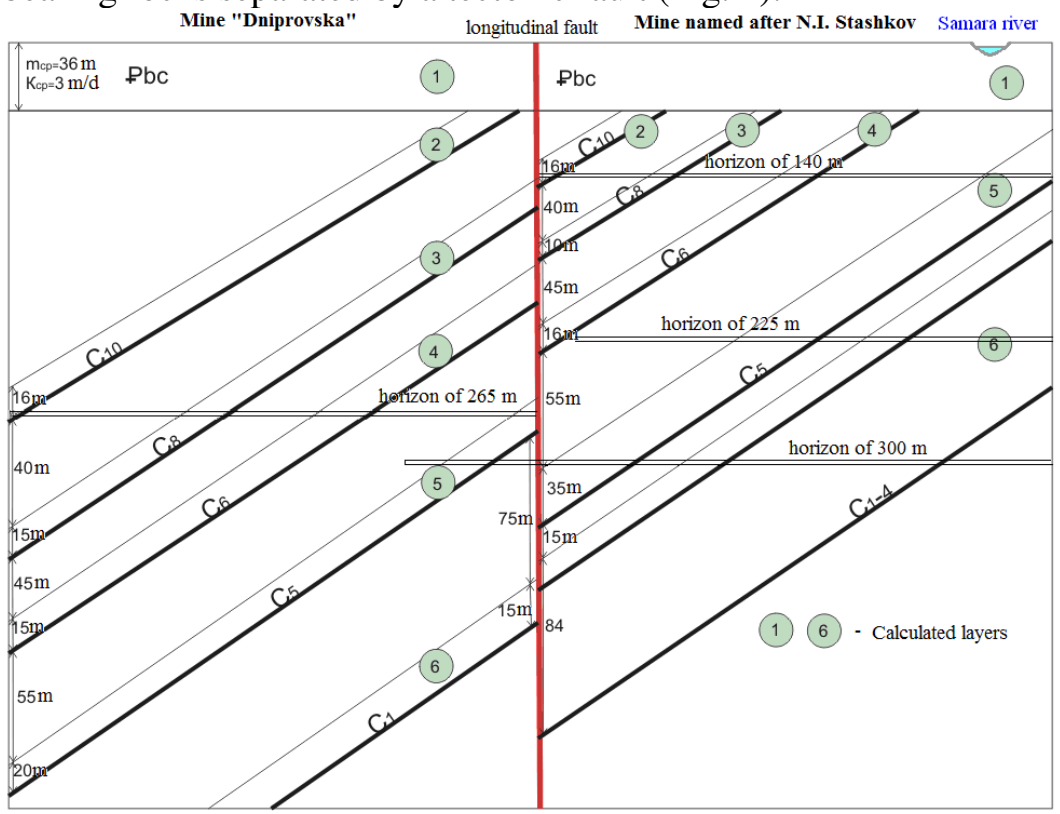

Fig. 1. Schematic vertical cross-section of the model 
The modelled area of $16.6 \mathrm{~km} \times 14 \mathrm{~km}$ was gridded by rectangular elements of $200 \mathrm{~m} \times 200 \mathrm{~m}$ size. The mine "Dniprovska" is located northeast of the tectonic fault and the mine named after N.I. Stashkov is southwest of the fault.

In the vertical section, the model reproduces a 6-layer rock stratum, with the first (upper) layer simulating the aquifer in permeable Buchak sediments, and the lower layers inclined at the angle of $2-5^{\circ}$. The latter consist of rocks in the zone of water permeable cracks and completely or partially mined out coal seams (Fig. 1).

The model has been validated through a series of calculations using known natural and disturbed hydrodynamic conditions and available monitoring data. This allowed evaluating groundwater levels and water inflows as well as the coefficients of boundary conditions, flow and capacity parameters in all permeable layers from the beginning of mining to nowadays.

The overall evaluation of model parameters has been made according to the available data on mine operation, including the records of drainage contours for the periods when clear trends (growth or decline) of water inflow change were identified (Fig. 2), and the records of groundwater level observations.

An analysis of water inflow evolution during coalmining made with using a developed groundwater flow model enabled drawing the following conclusions.

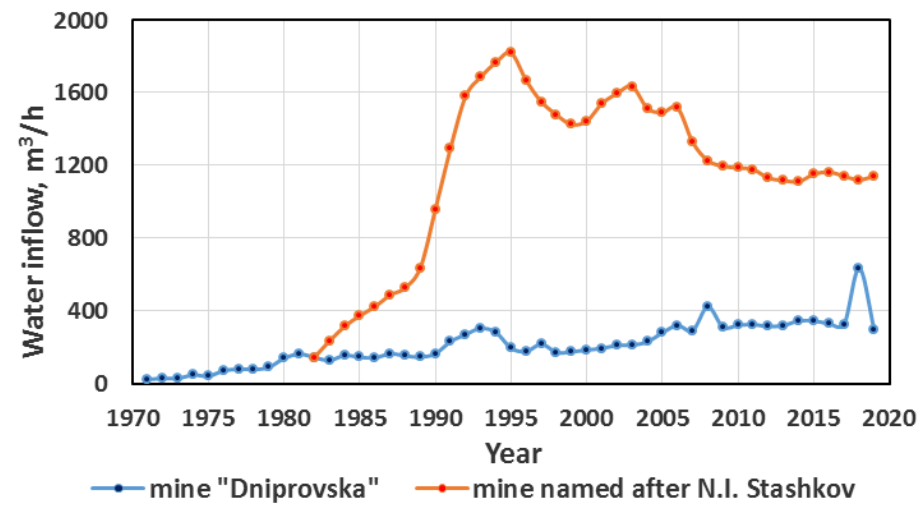

Fig. 2. Evolution of mine water inflows to the mine named after Stashkov and mine "Dniprovska" in time 
1. The actual values of water inflow can be balanced in the model only in the presence of transit zones of enhanced permeability if the transmissivity of intact coal seams varies at $0,5-1,5 \mathrm{~m}^{2} /$ days. In the coalfield, the zones of enhanced permeability are located in the sandstone strata of thickness up to $30-50 \mathrm{~m}$ and transmissivity up to $30 \mathrm{~m}^{2} /$ day; these formations lie in the top of the coal seam $\mathrm{C}_{5}$ contacting to water-abundant cover sediments. According to the lithologicalfacial analysis, these are alluvial sandstones in early carboniferous paleochannels and the patterns of their areal extension correlate with the zones of increased water seepages occurred during mining operations.

2. The water inflow to the mine depends by $70 \%$ on the resources withdrawn from the Meso-Cenozoic sediments, and the rest of water is accounted for the capacitive reserves in carboniferous rocks. As a result, a depression funnel up to $30 \mathrm{~m}$ depth appeared in the shallow Buchak aquifer, which led to changing groundwater flow directions near the Samara River. Under disturbed hydrogeological conditions, the river is transformed from the discharge zone into a recharge source for cover sediments and, consequently, provides an additional water source for flooding underground excavations.

3. Shifting the depression funnel in the Buchak aquifer correlates in time with the commissioning of coal seams in the direction of the zone where coal seams contact the sediment cover.

4. The maximum inflow of the Samara river runoff to the mine was recorded in course of mining of the $\mathrm{C}_{5}$ coal seam under the river floodplain $200 \mathrm{~m}$ from the riverbed when approaching to the borders of safe mining. In this zone, the maximum water inflow to the coal seam of $822 \mathrm{~m}^{3} / \mathrm{h}$ was provided owing to the river runoff of $570 \mathrm{~m}^{3} / \mathrm{h}$ or $69 \%$ in 1994.25 years later, the river runoff contribution to the outflow in the eastern coalfield part with the minimum thickness of subsoil sandstones far from the contact of the coal seam and BuchakKyiv sediments decreased to $63 \mathrm{~m}^{3} / \mathrm{h}$ or $9 \%$ (Table 1 ).

5. As known, the water inflow into a mine with coal seams directly contacting an aquifer does not correlate to the increase in the area of mining operations. In the areas mined out by roof collapse the permeability of carboniferous sediments varies in time. According to our estimations [16] its value increases 10-15 times after rocks were 
affected, then it is reducing by half in 5-10 years, and is approaching the initial permeability in $15-20$ years.

The hydrodynamic conditions of the seam $\mathrm{C}_{5}$ were assumed as the initial ones to predict rising groundwater level during flooding the mine. When mining the seam headway in 1994-1995 the maximum water inflows up to $650 \mathrm{~m}^{3} / \mathrm{h}$ were recorded. According to the mining plans, in the last simulated period two coalfields have been connected by the cross-drifts at the horizon $300 \mathrm{~m}$ through a tectonic fault zone with a displacement amplitude up to $40 \mathrm{~m}$, with no water occurrences having recorded during penetration in tectonically disturbed rocks. The water inflow to the stopes of the major and adjacent mining areas is evaluated by the model at $564 \mathrm{~m}^{3} / \mathrm{h}$ (measured value $551 \mathrm{~m}^{3} / \mathrm{h}$ ).

Table 1

Temporal evolution of water inflow to the coal seam $\mathrm{C}_{5}$

\begin{tabular}{l|c|c|c|c|c}
\hline \multicolumn{1}{c|}{ Year } & 1994 & 1998 & 2006 & 2015 & 2019 \\
\hline Total inflow to the mine, $\mathrm{m}^{3} / \mathrm{h}$ & 822 & 463 & 590 & 452 & 655 \\
\hline $\begin{array}{l}\text { Inflow to the mine from the Buchak } \\
\text { aquifer due to river runoff, } \mathrm{m}^{3} / \mathrm{h}\end{array}$ & 570 & 250 & 159 & 76 & 63 \\
\hline
\end{tabular}

After calibration, the modelled groundwater table in the Buchak aquifer was in good agreement with the available data of long-term groundwater monitoring records; the water inflows was also in good agreement with the measured values. This allowed to validate the groundwater flow model with the overall agreement up to $88 \%$ for all calculation layers, which was the ground to proceed with the predictive assessments of different flooding scenarios.

Modelling the mine flooding options

Option 1 means complete flooding of the mine named after N.I. Stashkov while keeping the inter-mine pillars. Modelling this option has been performed by disabling the first kind boundary condition in all calculation layers. The rate of flooding the mined out rocks and ground water rebound were found somewhat different. The mechanically affected rocks within the underground workings in the seams $C_{10}, C_{8}, C_{6}$ are expected to be flooded in a first year, since the mining has been shut down there long ago and the groundwater level has been partially restored to the initial elevation. As distinct from 
that, flooding the shafts and rebound of the ground and mine water levels in the seams $C_{5}, C_{4}$ is expected to take three years.

The groundwater level in carboniferous rocks will raise both in the main and additional parts of the coalfield above the $C_{5}$ seam. One month after flooding begins the gravitational capacity of the adjacent mining area will be exhausted and the level will be restoring under the elastic flow mode for three years (Fig. 3). Along with this, for the final period of flooding, a groundwater depression funnel will continue to remain in the adjacent area due to mining the $C_{10}$ seam and draining the main haulage roads along the $C_{8}$ seam of the "Dniprovska" mine.

The hydraulic response of the Buchak aquifer to shut off the mine water drainage at the mine named after N.I. Stashkov manifests itself in groundwater level restoration during three years with the appearance of flooded zones along the Samara River. At the same time, the depression pit will be shifted to the "Dniprovska" mine with a maximum drawdown of $11.3 \mathrm{~m}$ (Fig. 4).

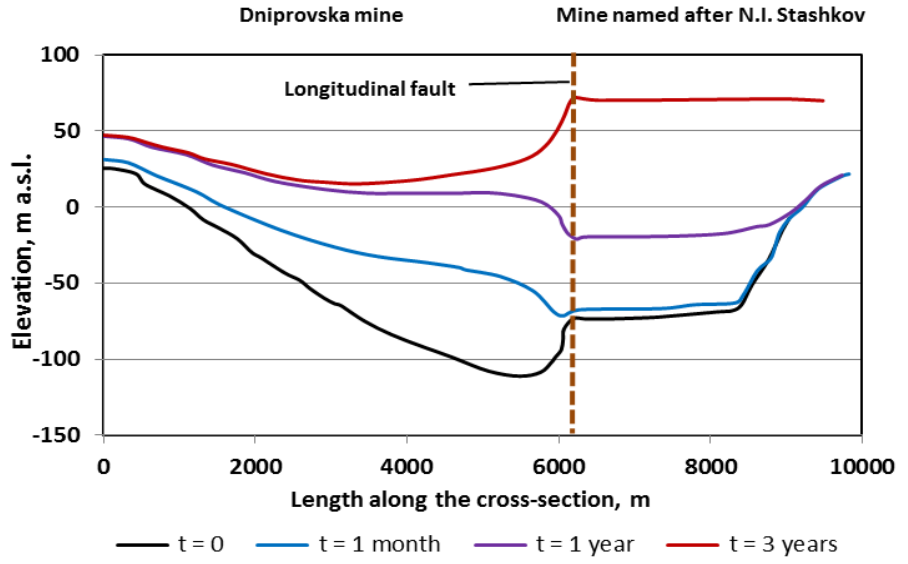

Fig. 3. Predicted groundwater level in the coalfield along the cross-section in Fig. 1 after drainage shut down at the moment $t=0$

The rising groundwater level within the mine named after N.I. Stashkov will result in the increase of water inflow to the "Dniprovska" mine by $50 \mathrm{~m}^{3} / \mathrm{h}$. The expected water inflows when mining the $C_{5}$ seam at the "Dniprovska" mine after 2025 will vary 
from $80 \mathrm{~m}^{3} / \mathrm{h}$ to $156 \mathrm{~m}^{3} / \mathrm{h}$ depending on the intensity of mining operations.

The zone of potential flooding and waterlogging remains, as in the pre-operational period, within the Samara River floodplain where the topographic elevations of the ground surface are below $+75 \mathrm{~m}$ a.s.l. These areas located outside the zone where rocks were mechanically affected by mining are remaining untouched.

Option 2 means flooding the mine named after N.I. Stashkov with maintaining the existing underground facilities of main drainage. On the one hand, keeping the drainage facilities on the horizon $225 \mathrm{~m}$ ( $-115 \mathrm{~m}$ a.s.l.) would enable lowering the groundwater level in cover sediments within the area of potential flooding typical for the pre-operational period by $4 \mathrm{~m}$. On the other hand, this option implies keeping the existing design of pumping out mineralized mine water in the long run and its further discharge into the Samara River at the rate of 5,87 million $\mathrm{m}^{3}$ per year, which should be considered environmentally unacceptable.

Option 3 means closing the mine with maintaining the drainage by submersible pumps installed in the auxiliary shaft. To ensure the environmental safety of shallow aquifers including prevention from waterlogging and keep the quality of groundwater and surface water it is necessary to maintain the mine water level below the bottom of cover sediments within the area of active mining.

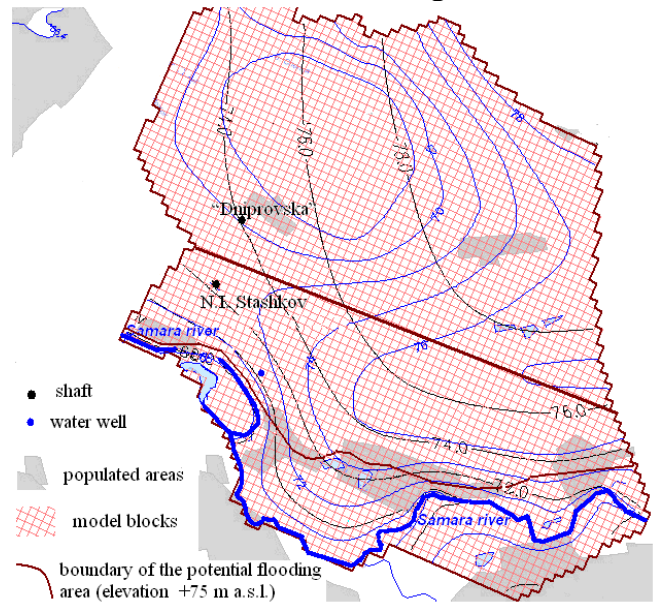

Fig. 4. Groundwater level in cover sediments in the pre-operational period (blue lines) and predicted for the period after mine flooding (black lines) 
To maintain the level of mine water and groundwater in carboniferous rocks within mined out zones at the safe elevation of $+20 \mathrm{~m}$ a.s.l. - that is the minimum elevation of the cover sediment bottom three sub-options of pumping by submersible pumps were examined numerically. It was suggested that the mine water level in the shaft could be maintained with the flow rate of $300-350 \mathrm{~m}^{3} / \mathrm{h}$ at three different positions above the sea level, namely $+10 \mathrm{~m},-10 \mathrm{~m}$, and $30 \mathrm{~m}$.

Comparison of responses of the aquifer in cover sediments to submersible pump operation shows that the radius of influence in all pump positions is much smaller than in option 2; the drawdown of the groundwater level in the zone of potential flooding is expected to vary from $0.1 \mathrm{~m}$ to $1.2 \mathrm{~m}$. In this case, the area of potential flooding can be reduced at most by $15 \%$.

The use of submersible pumps at the pumping level equivalent to the mining horizons $225 \mathrm{~m}$ (-115 m a.s.1.) or $300 \mathrm{~m}$ (-190 m a.s.1.) requires free water by-pass from the above horizons. Employing these drainage sub-options will maintain the hydrogeological conditions formed in the Samara River floodplain by 2020, i.e. the lowered groundwater level with respect to the pre-operational period. At the same time, these sub-options would require long-term drainage of mineralized mine water followed by its discharge to the Samara River, which is also environmentally unacceptable as in option 2 considered above.

Option 4 is an alternative option to protect the floodplain from flooding by installation of a water intake in the sandstone aquifer of high permeability in the paleochannel.

The option parameters including the water intake location were evaluated in course of model calibration taking into account the experience of mining the $\mathrm{C}_{5}$ coal seam in the close vicinity of the zone where the seam contacts the cover sediments under the Samara riverbed. In 1994-1995, abnormally high inflows into the mine of 1817 $\mathrm{m}^{3} / \mathrm{h}$ of which $649 \mathrm{~m}^{3} / \mathrm{h}$ in the $C_{5}$ seam have been recorded, with the drawdown in the Buchak aquifer of $30 \mathrm{~m}$ reaching the aquifer bottom. In that time, the sandstone paleochannel in the cover sediments above the $C_{5}$ seam with a thickness of 14-22 m was the additional zone of groundwater transit from the shallow aquifer. 
Identifying the causes and factors of abnormal water inflows allowed to recommend using the disturbed zone of sandstones under the riverbed in the interval of absolute elevations from $-55 \mathrm{~m}$ a.s.l. to $-50 \mathrm{~m}$ a.s.l. as an option of reducing the natural areas of flooding after mine closure. The proposed well location is shown in Fig. 4.

A sufficient drawdown in the zone of potential flooding up to $2 \mathrm{~m}$ can be reached by pumping water at the flow rate of $150 \mathrm{~m}^{3} / \mathrm{h}$ or 3600 $\mathrm{m}^{3} / \mathrm{d}$. Regarding to the rate of mine water level rebound evaluated by modelling the water intake should be commissioned in 6 months after flooding the mine begins. The average mineralization of pumped water estimated by the calculated water balance is expected to be of 2 $\mathrm{g} / \mathrm{dm}^{3}$; this water can be used as process water.

This option of environmental protection is the most appropriate with the synchronous monitoring of groundwater and mine water levels and gradual increase of the flow rate $Q$ according to the proposed correlation $f(S)$ depending on drawdown $S$ (Fig. 5); this enables using technical water for general use of the mining company and simultaneously draining $80-90 \%$ of the flooded area.

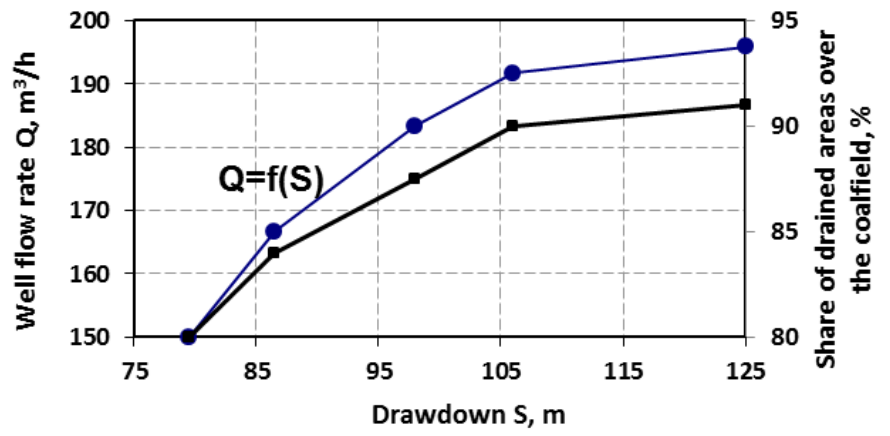

Fig. 5. Recommended flow rate of the water intake depending on the drawdown and estimation of its draining effect

\section{Conclusions and recommendations}

The study explored the temporal and spatial patterns of groundwater flow in the most watered mine in Ukraine named after N.I. Stashkov (Western Donbas) in order to optimize environment engineering measures to be apply during its forthcoming closure and the postmining period. 
Numerical modelling showed that the groundwater level rebound in carboniferous and cover sediments is expected to develop in the areas of potential flooding and waterlogging within the Samara River floodplain existed in the pre-operational period; these areas were not mined out and located outside the zone of mechanical impact on rocks.

Having applied the calibrated model we assessed the hydrodynamic conditions after the mine closure and compared three options to mitigate the environmental impacts of flooding. The use of submersible pumps to dewater the shaft above the horizon $140 \mathrm{~m}$ was found to be low effective in terms of reducing the area of flooding because of pump location on the periphery of the coalfield. Installing the drainage on the horizon of $225 \mathrm{~m}$ would allow approaching the hydrogeological conditions that existed in the pre-mining period, but it may require long-term pumping of mineralized mine water and its discharge into the Samara River, which is not environmentally accepted.

Based on the results of inverse modelling for the period of abnormally high water inflows into the mine, the option of installing the groundwater intake has been recommended. It allows using the water permeable sandstone stratum in the paleochannel in the top of the $C_{5}$ coal seam as a transit zone of high permeability to prevent the Samara river floodplain from flooding.

The results of ground water flow modelling and hydrodynamic assessments on the consequences of flooding the mine are the basis of the closure design being developed for the mine named after N.I. Stashkov.

\section{Acknowledgments}

This study was supported by DTEK Pavlogradugol PJSC and, particularly, its local unit "Ternovske Mining Management". The assistance of company staff in conducting research and implementing the results is highly acknowledged by the authors.

\section{References}

1. Wolkersdorfer, C., \& Bowell, R. (2004). Contemporary Reviews of Mine Water Studies in Europe, part 1. Mine Water and the Environment, 23(4), 162-182.

2. Sadovenko, I., Zagrytsenko, A., Podvigina, O., \& Dereviagina, N. (2016). Assessment of environmental and technical risks in the process of mining on the basis of numerical simulation of geofiltration. Mining of Mineral Deposits, 10(1), 37 43. http://dx.doi.org/10.15407/mining10.01.037

3. Younger, P. L., Jenkins, D. A., Rees, B., Robinson, J., Jarvis, A. P., Ralph, J., Coulton, R. H. (2004). Mine waters in Wales: pollution, risk management and 
remediation. Urban geology in Wales. National Museums and Galleries of Wales Geological Series, 138-154.

4. Mine closure and post-mining management. International state-the-art. (2008). International Commission on Mine Closure. International Society for Rock Mechanics.

5. Babu, D. K., \& Pinder, G. F. (1984). A finite element-finite difference alternating direction algorithm for three dimensional groundwater transport. In Finite Elements Water Resour.: Proc. 5th Int. Conf.. Berlin.

6. Quiros, A. G., \& Fernández-Álvarez, J. P. (2019). Conceptualization and finite element groundwater flow modeling of a flooded underground mine reservoir in the Asturian Coal Basin, Spain. Journal of Hydrology, 578, [124036]. https://doi.org/10.1016/j.jhydrol.2019.124036

7. DMT GmbH \& Co. KG (2011) BoxModel Concept: ReacFlow3D, Program description accompanying BoxModel documentation, Germany.

8. Banks, D. (2001). A variable-volume, head-dependent mine water filling model. Ground Water, 39(3), 362-365.

9. Sadovenko, I., \& Rudakov, D. (2010). Dynamics of groundwater flow mass transfer during active and closing mining operations. Dnipropetrovsk: National Mining University.

10. Westermann, S., Rudakov, D., Reker, B., \& Melchers, C. (2019). Ein neuer Blick auf Grubenwasseranstiegsprozesse - ausgewählte Beispiele aus dem deutschen Steinkohlenbergbau. Markscheidewesen, 126(1), 30-38.

11. Hydrogeologist Guide (1967). Moscow: Nedra.

12. Sadovenko, I., Zahrytsenko, A., Podvigina, O., Dereviahina, N., \& Brzeźniak, S. (2018). Methodical and Applied Aspects of Hydrodynamic Modeling of Options of Mining Operation Curtailment. Solid State Phenomena, 36-43. https://doi.org/10.4028/www.scientific.net/SSP.277.36

13. Norvatov, Y.A., Petrova, I.B., Kotlov, S.N., \& Saveliev, D.I. (2010). Scientific and methodological principles of the analysis and prediction of hydrogeological conditions of mine abandonment. International Mining Conference Advanced Mining for Sustainable Development, (597-600). Hanoi: Vietnam Mining Science and Technology Association.

14. Zahrytsenko, A., Podvigina, O., \& Dereviahina, N. (2018). Scientific and methodological foundations to develop numerical hydrodynamical models of mine fields in Donbas. E3S Web of Conferences, 60. Retrieved from https://doi.org/10.1051/e3sconf/20186000034.

15. Sadovenko, I., Rudakov, D., \& Podvigina, O. (2010). Analysis of hydrogeodynamics in a mining region during exploitation till closure of coal mines. New Techniques and Technologies in Mining: School of Underground Mining 2010, 6169.

16. Zahrytsenko, A.N. (2018). Parametric basis of water regulation during mine operation in complex hydrodynamic conditions of Western Donbass. Sci. Bulletin of Taurida National V.I. Vernadsky University. Technical Sciences, 29(68), Part 2, 122 128. 